УДК 657.433:336.27:005.52

DOI: 10.15673/fie.v10i4.1134

\author{
Ступницька Т.М. \\ кандидат економічних наук, доцент \\ кафедра обліку та аудиту \\ E-mail: t.stupnitska@gmail.com
}

\author{
Бамбуляк I.M. \\ магістрант \\ кафедра обліку та аудиту \\ E-mail: $\underline{b}$ irina mih@ukr.net
}

\author{
Маркова Т.Д. \\ кандидат економічних наук, доцент \\ кафедра обліку та аудиту \\ E-mail: markova.tetiana17@gmail.com \\ Кулік Н.M. \\ магістрант \\ кафедра обліку та аудиту \\ Одеська національна академія харчових технологій \\ вул. Канатна, 112, м. Одеса, Україна, 65039 \\ E-mail: natali.kulik.1996@mail.ru
}

\title{
КРЕДИТОРСЬКА ЗАБОРГОВАНІСТЬ ПІДПРИЕМСТВА: ОЦІНКА ТА МЕХАНІЗМИ УПРАВЛІННЯ
}

У статті розглянуто економічний зміст та підходи до визначення категорії «кредиторська заборгованість» за нормативно-правовими актами та в економічній літературі. Проведено дослідження теоретичних підходів та їх практичного використання щодо проведення аналізу кредиторської заборгованості в сучасних умовах, з виділенням окремих його етапів. Враховуючи різні методи та строки погашення кредиторської заборгованості проведена її оцінка величини, структури та динаміки з використанням прийомів горизонтального і вертикального аналізу на прикладі даних фінансової звітності підприємства харчової промисловості. Також досліджено структуру кредиторської заборгованості за строками утворення з метою з'ясування стану платіжної дисципліни. Проведено комплексне оцінювання за системою відносних показників для визначення стану фінансової стійкості та платоспроможності. Для визначення домінуючого виду зобов'язання проведено порівняльний аналіз дебіторської та кредиторської заборгованості. Визначені механізми ефективного управління для своєчасного реагування поточної кредиторської заборгованості, правильного відображення у фінансовій звітності підприємства та безперебійної роботи та надійності на арені бізнесу.

Ключові слова: кредиторська заборгованість, економічний зміст категорії «кредиторська заборгованість», етапи аналізу кредиторської заборгованості, аналіз, управління.

This work is licensed under a Creative Commons Attribution 4.0 International License http://creativecommons.org/licenses/by/4.0/

Постановка проблеми та їі зв'язок з важливими науковими та практичними завданнями. В процесі здійснення фінансово-господарської діяльності будь-яке підприємство проводить розрахунки за отримані товари, роботи, послуги, сплачує податки, тобто виникає кредиторська заборгованість.

Позикові кошти є одним із джерел формування засобів для підприємств. Але, останнім часом, спостерігається тенденція, що залучені позикові засоби спрямовані не на розвиток та ефективність виробництва, а, навпаки, на погашення своїх зобов'язань перед іншими кредиторами. Крім того, несвоєчасність обліку, оцінки та погашення поточної кредиторської заборгованості призводить до порушення дисципліни як фінансової, так й розрахункової. Сучасні умови ведення фінансово-господарської діяльності спонукає до об' єктивного оцінювання довіри до своїх партнерів, фінансової стійкості та платоспроможність. Стабільність економічної сфери неможлива без фінансової стійкості суб'єктів господарювання так як, саме стійкість $є$ основою міцного їх становища на ринку та конкурентоспроможності. Так, за даними Державної служби статистики України, поточні зобов'язання i забезпечення підприємств за видами економічної діяльності станом на 31.12.2017 року [1] $\epsilon$ на 2,06\% більше ніж оборотні активи [2]. Крім того, частка кредиторської заборгованості складає 50,76\% від поточних зобов'язань, що свідчить про фінансову залежність.

Отже, важлива та відповідальна ділянка обліку на підприємстві $є$ розрахунки 3 постачальниками та підрядниками, іiі оцінка і найголовніше - ефективне іiі управління для своєчасного реагування поточної кредиторської заборгованості, надання відстрочки платежу, правильного відображення у фінансовій звітності підприємства та безперебійної роботи та надійності на арені бізнесу.

Кредиторська заборгованість надає можливість тимчасового використання позикових коштів, але, 3 іншого боку це призводить до зменшення показників платоспроможності і ліквідності. Окрім цього наявність простроченої заборгованості може призвести до погіршення іміджу підприємства. При правильному управлінні кредиторською заборгованістю можна усунути негативні наслідки іï наявності. Це можливе за умови правильно організованої системи обліку та аналізу кредиторської заборгованості [3]. 
Аналіз останніх публікацій 3 проблеми. 3 визначеної проблематики питання обговорюються як на науково-теоретичному рівні, так і на практиці. Важливі питання організації розрахунків за кредиторською заборгованістю та іiі аналізу розкрито в працях таких вітчизняних вчених, як Ф.Ф. Бутинця, Є.В. Калюги, А.М. Ужви, Н.М. Бразілій, І.О. Коблянської, О.В. Маркуса, Н.В. Чебанової, Т.І. Єфіменка, В.М. Івахненко, Н.М. Ткаченко, Л.В. Кручак, О.Ф.Томчука, Ю. М. Тютюнник, К. Багрій, А.Г. Семенова, С. А. Король, В.І.Матюха, Г.В.Мисака, Н.В. Новицької, І.М.Мягких, Є.В. Мних, О.П. Антонюка, Т.М. Ступницької, Н.М. Купріної, П.Я. Попович, Г.В. Савицька, Томас П.Карлін, Альберт Р.Маклін та багато інших. Проте, перелік важливих питань методики оцінки та механізми управління кредиторською заборгованістю залишаються не висвітлені та вимагають як теоретичної, так і практичної уваги та підтверджують значимість даного дослідження.

Формування цілей дослідження. Метою статті $\epsilon$ аналіз визначення поняття, економічного змісту категорії «кредиторська заборгованість» за нормативно-правовими актами та в економічній літературі, а також дослідження теоретичних підходів та їх практичного використання щодо проведення аналізу кредиторської заборгованості в сучасних умовах та визначення оптимальних механізмів ऑiі ефективного управління.

Виклад основних результатів та їх обгрунтування. Кредиторська заборгованість виникає в процесі здійснення фінансово-господарської діяльності будь-якого підприємства. Поняття «кредиторська заборгованість» в економічній літературі досить часто ототожнюється $з$ поняттям «зобов’язання». В економічній літературі відсутній єдиний підхід до визначення категорії «кредиторська заборгованість». У нормативно-правових актах також є деякі відмінності щодо трактування цього поняття. Тому, на наш погляд, дане питання розглядається у двох напрямах: згідно з вимогами нормативно-правової бази та за науковим підходом (табл. 1).

Таблиця 1

Визначення поняття «кредиторська заборгованість» та «зобов'язання» різними джерелами*

\begin{tabular}{|c|c|}
\hline Джерело & Визначення \\
\hline $\begin{array}{l}\text { Кодекс Цивільного } \\
\text { захисту України [4] }\end{array}$ & $\begin{array}{l}\text { Зобов’язанням є правовідношення, в якому одна сторона (боржник) зобов’язана } \\
\text { вчинити на користь другої сторони (кредитора) певну дію (передати майно, вико- } \\
\text { нати роботу, надати послугу, сплатити гроші тощо) або утриматися від вчинення } \\
\text { певної дії (негативне зобов’язання), а кредитор має право вимагати від боржника } \\
\text { виконання його обов'язку. }\end{array}$ \\
\hline $\begin{array}{l}\text { Закон України «Про бух- } \\
\text { галтерській облік та фі- } \\
\text { нансову звітність в Укра- } \\
\text { їні [5] }\end{array}$ & $\begin{array}{l}\text { Зобов’язання - заборгованість підприємства, що виникла внаслідок минулих подій } \\
\text { і погашення якої в майбутньому, як очікується, приведе до зменшення ресурсів } \\
\text { підприємства, що втілюють у собі економічні вигоди. }\end{array}$ \\
\hline $\begin{array}{l}\text { МСБО №37 } \\
\text { «Забезпечення, умовні } \\
\text { зобов’язання та умовні } \\
\text { активи» [6] }\end{array}$ & $\begin{array}{l}\text { Зобов’язання - існуюче зобов’язання суб’єкта господарювання, яке виникає в ре- } \\
\text { зультаті минулих подій і погашення якої, за очікуванням, призведе до вибуття ре- } \\
\text { сурсів суб'єкта господарювання, котрі втілюють у собі економічні вигоди }\end{array}$ \\
\hline $\begin{array}{l}\text { П(С)БО №11 } \\
\text { «Зобов’язання» [7] }\end{array}$ & $\begin{array}{l}\text { Непередбачене зобов’язання - це: } \\
\text { 1) зобов’язання, що може виникнути внаслідок минулих подій та існування якого } \\
\text { буде підтверджено лише тоді, коли відбудеться або не відбудеться одна чи більше } \\
\text { невизначених майбутніх подій, над якими підприємство не має повного контролю; } \\
\text { або } \\
\text { 2) теперішнє зобов'язання, що виникає внаслідок минулих подій, але не визнаєть- } \\
\text { ся, оскільки малоймовірно, що для врегулювання зобов'язання потрібно буде ви- } \\
\text { користати ресурси, які втілюють у собі економічні вигоди, або оскільки суму зо- } \\
\text { бов’язання не можна достовірно визначити. }\end{array}$ \\
\hline $\begin{array}{l}\text { Матюха B.I., } \\
\text { Мисака Г.В. [8] }\end{array}$ & $\begin{array}{l}\text { Кредиторська заборгованість - це можливість підприємства тимчасово використо- } \\
\text { вувати запозичені ресурси, але } 3 \text { іншого боку також зменшує показники плато- } \\
\text { спроможності і ліквідності. }\end{array}$ \\
\hline Новицька Н.В. [9] & $\begin{array}{l}\text { Кредиторська заборгованість - це фінансова категорія, яка є сукупністю фінансо- } \\
\text { вих вимог до підприємства внаслідок здійснення певних дій на користь інших осіб, } \\
\text { які є юридично оформленими певними документами та набувають форми довг-- } \\
\text { строкового або поточного (залежно від строковості) пасиву (зобов'язання) і є дже- } \\
\text { релом залучених коштів підприємства. }\end{array}$ \\
\hline Мягких I.M. [10] & $\begin{array}{l}\text { Кредиторська заборгованість - заборгованість, що виникає при розрахунках з пос- } \\
\text { тачальниками і іншими кредиторами; тимчасове використання в грошовому обігу } \\
\text { коштів кредиторів. }\end{array}$ \\
\hline Томчук О.Ф. [11] & $\begin{array}{l}\text { Кредиторська заборгованість є різновидом комерційного кредиту, який виступає } \\
\text { важливим фактором стабілізації фінансового стану підприємства. }\end{array}$ \\
\hline
\end{tabular}


Продовження табл. 1

\begin{tabular}{|c|c|}
\hline Джерело & Визначення \\
\hline $\begin{array}{l}\text { Бутинець Ф.Ф., } \\
\text { Горецька Л.Л. [12, с. 387] }\end{array}$ & $\begin{array}{l}\text { Кредиторська заборгованість - це форма розрахунку за товари та послуги, прид- } \\
\text { бані під час регулярно повторюваних операцій підприємства та використовувані } \\
\text { для переробки (як сировина) або для подальшого перепродажу. }\end{array}$ \\
\hline Лишиленко О.В. [13, с. 15] & $\begin{array}{l}\text { Кредиторська заборгованість - заборгованість підприємства перед іншими } \\
\text { суб’єктами підприємницької діяльності (постачальниками, підрядниками, покуп- } \\
\text { цями) за поставлені від них засоби і предмети праці, виконані роботи або отри- } \\
\text { ману передоплату. }\end{array}$ \\
\hline Бабаєва Ю.А. [14,с. 36] & $\begin{array}{l}\text { Кредиторська заборгованість - це заборгованість організації іншим юридичним і } \\
\text { фізичним особам, що з’являється в результаті розриву в часі між наданням това- } \\
\text { рно-матеріальних цінностей, надходженням товарно-матеріальних цінностей, } \\
\text { наданням послуг, надходженням попереднього грошового авансу й датою їх фак- } \\
\text { тичної оплати й виконання зобов'язань перед сторонніми особами. }\end{array}$ \\
\hline Гетьман В.Г. [15, с. 18] & $\begin{array}{l}\text { Кредиторська заборгованість - борги організації перед постачальниками за това- } \\
\text { ри й послуги, по випущених векселях, до цієї ж групи відноситься заборгованість } \\
\text { своїм працівникам по нарахованій, але не виплаченій заробітній платі, що вини- } \\
\text { кає в зв’язку з тим, що миттєві нарахування не збігаються в часі. Таким же є ме- } \\
\text { ханізм утворення заборгованості перед органами соціального страхування й за- } \\
\text { безпечення по внесках єдиного соціального податку, перед бюджетом по подат- } \\
\text { ках. }\end{array}$ \\
\hline Ковальчук І.В. [16, с. 217] & $\begin{array}{l}\text { Кредиторська заборгованість - це короткострокові зобов’язання підприємств } \\
\text { перед постачальниками ресурсів, за розрахунками з бюджетом або перед іншими } \\
\text { кредиторами. }\end{array}$ \\
\hline Іванілов О.С. [17, с. 276] & $\begin{array}{l}\text { Кредиторська заборгованість означає використання коштів, які не належать під- } \\
\text { приємству (заборгованість по акцептованих та інших розрахункових документах, } \\
\text { строк сплати яких не настав; заборгованість за несплаченими у строк рахунками; } \\
\text { заборгованість за платежами до бюджету; за виданими векселями; за комерцій- } \\
\text { ними кредитами тощо) }\end{array}$ \\
\hline Шило В.П. [18, с. 131-132] & $\begin{array}{l}\text { Кредиторська заборгованість представляє найбільш короткостроковий вид вико- } \\
\text { ристовуваних підприємством позикових коштів. Формування кредиторської за- } \\
\text { боргованості обумовлене різними термінами нарахування коштів на рахунки і } \\
\text { погашення зобов'язань. Іншими словами, кошти з моменту нарахування вже не є } \\
\text { власністю підприємства, але використовуються ним до настання терміну пога- } \\
\text { шення зобов'язань. }\end{array}$ \\
\hline Черкав Д.І. [19,с. 453] & $\begin{array}{l}\text { Кредиторська заборгованість виникає (або погашається) при здійсненні фірмою } \\
\text { будь-яких операцій, що пов'язані з рухом грошей, ресурсів або прийняттям на } \\
\text { себе відповідних зобов'язань. }\end{array}$ \\
\hline Цал-Цалко Ю.С. [20, с. 260] & $\begin{array}{l}\text { Кредиторська заборгованість - це тимчасове залучення активів у господарську } \\
\text { діяльність підприємства за рахунок тимчасово безоплатного одержання майна } \\
\text { інших суб'єктів господарювання. }\end{array}$ \\
\hline Ткаченко Н.М. [21, с. 683] & $\begin{array}{l}\text { Кредиторська заборгованість - це тимчасово залучені суб’єктом у власне корис- } \\
\text { тування грошові кошти, які підлягають поверненню юридичній або фізичній } \\
\text { особі. }\end{array}$ \\
\hline $\begin{array}{l}\text { ЧебановаН.В., } \\
\text { Василенко Ю.А. [22, с. 413] }\end{array}$ & $\begin{array}{l}\text { Кредиторська заборгованість є правовою категорією, специфічною частина май- } \\
\text { на організації, яка виступає предметом правовідносин між фірмою та її кредито- } \\
\text { рами. Фірма володіє і використовує кредиторську заборгованість, але вона має } \\
\text { повернути або виплатити цю частину активів кредиторам, які мають права на } \\
\text { них. Таким чином, ця частина майна є боргами фірми, чужим майном, чужими } \\
\text { коштами, що знаходяться у володінні фірми-боржника. }\end{array}$ \\
\hline
\end{tabular}

*Узагальнено авторами на підставі аналізу джерел [4-22]

В результаті узагальнення тлумачення поняття «зобов'язання» та «кредиторська заборгованість» різними джерелами, на нашу думку, кредиторська заборгованість - це фінансова угода між двома суб'єктами господарювання, в якій одна сторона тимчасово позичає комерційні кошти для товарногрошового обігу, а інша - зобов'язується повернути грошовий борг у вказаний термін.

Оскільки, кредиторська заборгованість є по- казником, що впливає на фінансову стійкість підприємства, вчені розглядають різні методики їі аналізу. Так, Мягких I.M. [10] виділяє нормативний метод, в основі якого покладено систему фінансових норм та техніко-економічних нормативів, що характеризують абсолютну величину заборгованості, а також джерела їх фінансового забезпечення. Крім того, автор зазначає, що норми та нормативи можуть бути класифіковані за категоріями контрагентів, видів грошових ро- 
розрахунків, строків погашення. Метод розрахунково-аналітичний полягає у тому, що на основі фінансово-економічних показників заборгованості за попередні періоди, які беруться за базові, та індексів їх зміни у плановому періоді відповідно до зміни моделі грошових розрахунків визначається планова величина заборгованості підприємства. Розрахунковоаналітичний метод також повинен, на думку автора [10], доповнювати метод оптимізації фінансових рішень i бути інструментарієм економікоматематичного моделювання розрахункових операцій підприємства.

На основі досліджень різних методик проведення аналізу господарської діяльності підприємств, авторами Гарасим П.Н., Лобода Н.А., Гарасим Н.П. запропонована методика аналізу зобов'язань, основним завданням якої виявлення ознак неплатоспроможності підприємства та запобігання його банкрутству. Сутність запропонованої методики полягає у вивченні структури зобов'язань, їх оборотності, визначенні ступеня платоспроможності та ліквідності підприємства, які розраховують на основі даних звітності, а також у здійсненні розрахунку граничної суми зобов'язань під впливом таких чинників як доходи, витрати діяльності, оборотні активи підприємства [23].

Разом з тим багато сучасних вчених вважають, що аналіз кредиторської заборгованості не може бути розглянутий в повному, або у найбільш точному обсязі за одним методом аналізу. Так, наприклад, такі автори як Івахненко В.М., Мних С.В., Попович П.Я., Савицька Г.В., Томас П. Карлін, Альберт Р.Маклін використовують одразу декілька класичних методів аналізу кредиторської заборгованості. Основними 3 них є:

- горизонтальний (трендовий) аналіз - у процесі аналізу визначають абсолютні та відносні зміни величин різних статей звітності за попередній або звітний період;

- вертикальний аналіз полягає в розрахунку частки окремих складових фінансових показників та вплив кожної складової на результат в цілому, тобто вивчення структури окремих показників на початок i кінець періоду; основними його видами є: структурний аналіз активів; структурний аналіз капіталу; структурний аналіз грошових потоків; результати такого аналізу використовуються для проведення ефективної інвестиційної діяльності й раціонального використання грошових коштів підприємства [24];

- факторний аналіз - за його допомогою виявляються причини зміни абсолютних і відносних фінансових показників, і розраховується вплив факторів на зміну фінансового показника;

- порівняльний аналіз базується на співставленні значень окремих груп аналогічних показників; основними його видами $є$ порівняльний аналіз фінансових показників даного підприємства 3: середньогалузевими показниками; 3 аналогічними показниками підприємств-конкурентів; порівняльний аналіз звітних та планових (нормативних) показників; за результатами такого аналізу визначаються тактичні i стратегічні шляхи господарювання в жорстких умовах конкуренції;

- коефіцієнтний аналіз застосовується для розрахунку рівня і динаміки відносних показників фінансового стану: коефіцієнтів оцінки фінансової стійкості; коефіцієнтів оцінки платоспроможності (ліквідності); коефіцієнтів оцінки оборотності активів та капіталу; коефіцієнтів оцінки рентабельності.

У табл. 2 наведено систематизований перелік показників для проведення аналізу кредиторської заборгованості, що пропонуються сучасними економістами.

Таблиця 2

Підходи до розрахунку показників для проведення аналізу кредиторської заборгованості за працями відомих науковців*

\begin{tabular}{|c|c|c|c|}
\hline Автор & Назва показника & Порядок розрахунку & Значення показника \\
\hline \multirow{3}{*}{ Івахненко В. М. } & $\begin{array}{l}\text { Коефіцієнт співвідношен- } \\
\text { ня дебіторської і креди- } \\
\text { торської заборгованості }\end{array}$ & $\begin{array}{l}\text { К сдк = Дебіторська забор- } \\
\text { гованість (Дз) / Кредиторсь- } \\
\text { ка заборгованість (Кз) }\end{array}$ & $\begin{array}{l}\text { визначає величину дебіторської } \\
\text { заборгованості, що доводиться } \\
\text { на } 1 \text { грн. кредиторської (причому } \\
\text { оптимальне значення коефіцієн- } \\
\text { та варіюється від } 0,9 \text { до } 1,0 \text {, тоб- } \\
\text { то кредиторська заборгованість } \\
\text { повинна не більше ніж на десять } \\
\text { відсотків перевищувати дебітор- } \\
\text { ську) }\end{array}$ \\
\hline & $\begin{array}{l}\text { Коефіцієнт оборотності } \\
\text { кредиторської заборгова- } \\
\text { ності }\end{array}$ & $\begin{array}{l}\text { Коб.к = Грошові кошти (Гк)/ } \\
\text { / Середня кредиторська за- } \\
\text { боргованість за звітний пе- } \\
\text { ріод (Кс) }\end{array}$ & $\begin{array}{l}\text { показує збільшення або змен- } \\
\text { шення комерційного кредиту, } \\
\text { який надається підприємству } \\
\text { (збільшення коефіцієнта означає } \\
\text { збільшення швидкості оплати } \\
\text { заборгованості, зменшення - } \\
\text { показує збільшення купівлі в } \\
\text { кредит). }\end{array}$ \\
\hline & $\begin{array}{l}\text { Середній строк оборотнос- } \\
\text { ті кредиторської заборго- } \\
\text { ваності }\end{array}$ & $\begin{array}{l}360 \text { / Коефіцієнт оборотнос- } \\
\text { ті кредиторської заборгова- } \\
\text { ності }\end{array}$ & $\begin{array}{l}\text { вказує на період, протягом якого } \\
\text { компанія використовує кошти } \\
\text { своїх постачальників і підрядни- } \\
\text { ків }\end{array}$ \\
\hline
\end{tabular}


Продовження табл.2

\begin{tabular}{|c|c|c|c|}
\hline Автор & Назва показника & Порядок розрахунку & Значення показника \\
\hline Мних С. В. & $\begin{array}{l}\text { Середня тривалість вико- } \\
\text { ристання кредиторської } \\
\text { заборгованості в обороті } \\
\text { підприємства }\end{array}$ & $\begin{array}{l}\text { Середні залишки кредитор- } \\
\text { ської заборгованості за ана- } \\
\text { лізований період / Загальна } \\
\text { сума обороту за розрахун- } \\
\text { ками з кредиторами }\end{array}$ & $\begin{array}{l}\text { визначає середню тривалість } \\
\text { використання позикових коштів, } \\
\text { а не тривалість обороту, на від- } \\
\text { міну від коефіцієнта оборотності } \\
\text { кредиторської заборгованості в } \\
\text { днях }\end{array}$ \\
\hline \multirow[b]{2}{*}{ Попович П. Я. } & $\begin{array}{l}\text { Оборот кредиторської за- } \\
\text { боргованості }\end{array}$ & $\begin{array}{l}\text { Сума закупівель / Сальдо } \\
\text { кредиторської заборговано- } \\
\text { сті }\end{array}$ & $\begin{array}{l}\text { показує кількість оборотів, які } \\
\text { здійснила кредиторська заборг-- } \\
\text { ваність протягом року }\end{array}$ \\
\hline & $\begin{array}{l}\text { Тривалість обороту креди- } \\
\text { торської заборгованості }\end{array}$ & $\begin{array}{l}\text { Сальдо кредиторської забо- } \\
\text { ргованості / Сума закупівель }\end{array}$ & $\begin{array}{l}\text { вказує на період, протягом якого } \\
\text { компанія використовує кошти } \\
\text { своїх постачальників і підрядни- } \\
\text { ків (оцінює ефективність управ- } \\
\text { ління кредиторською заборгова- } \\
\text { ністю) }\end{array}$ \\
\hline \multirow{4}{*}{ Савицька Г. В. } & $\begin{array}{l}\text { Тривалість використання } \\
\text { кредиторської заборгова- } \\
\text { ності }\end{array}$ & $\begin{array}{l}\text { Середні залишки кредиторсь- } \\
\text { кої заборгованості · Дні звіт- } \\
\text { ного періоду / Сума погаше- } \\
\text { ної кредиторської заборгова- } \\
\text { ності за звітний рік }\end{array}$ & $\begin{array}{l}\text { показує середнє число днів, не- } \\
\text { обхідних для розрахунків з пос- } \\
\text { тачальниками і підрядниками та } \\
\text { іншими суб'єктами-кредиторами, } \\
\text { які обслуговують поточну діяль- } \\
\text { ність підприємства в частині } \\
\text { придбання. }\end{array}$ \\
\hline & $\begin{array}{l}\text { Коефіцієнт оборотності за } \\
\text { виданими векселями }\end{array}$ & $\begin{array}{l}\text { Сума погашених зо- } \\
\text { бов’язань за векселями ви- } \\
\text { даними / Середнє сальдо за } \\
\text { рахунком «Векселі видані» }\end{array}$ & $\begin{array}{l}\text { показує ту частину боргових } \\
\text { зобов'язань, несвоєчасне пог- } \\
\text { шення яких призведе до опроте- } \\
\text { стування векселів, виданих підп- } \\
\text { риємством, а отже, до додатко- } \\
\text { вих витрат і втрати ділової репу- } \\
\text { тації. }\end{array}$ \\
\hline & $\begin{array}{l}\text { Тривалість заборгованості } \\
\text { за виданими векселями }\end{array}$ & $\begin{array}{l}\text { Середнє сальдо за рахунком } \\
\text { «Векселі видані»· Дні пері- } \\
\text { оду / Сума погашених зо- } \\
\text { бов’язань за векселями за } \\
\text { період, що аналізується }\end{array}$ & $\begin{array}{l}\text { фактичне значення тривалості } \\
\text { вексельного боргу порівнюють зі } \\
\text { середніми термінами платежів, } \\
\text { обумовлених у векселях, і з'ясо- } \\
\text { вують причини прострочення } \\
\text { платежів по векселях, а також } \\
\text { суму додатково сплачених санк- } \\
\text { цій. }\end{array}$ \\
\hline & $\begin{array}{l}\text { Порівняння суми дебітор- } \\
\text { ської і кредиторської забо- } \\
\text { ргованості }\end{array}$ & $\begin{array}{l}\text { Сума дебіторської заборго- } \\
\text { ваності на звітну дату / Сума } \\
\text { кредиторської заборговано- } \\
\text { сті на звітну дату }\end{array}$ & $\begin{array}{l}\text { розмір показника характеризує } \\
\text { мінімальну суму на поповнення } \\
\text { оборотних коштів; значення ко- } \\
\text { ефіцієнта повинно бути менше } \\
1,0 \text { (від'ємне значення показника } \\
\text { свідчить про відсутність оборот- } \\
\text { них коштів, а його високе зна- } \\
\text { чення показує, що ресурси замо- } \\
\text { рожені в оборотних коштах. }\end{array}$ \\
\hline \multirow{3}{*}{$\begin{array}{l}\text { Томас П. Карлін, } \\
\text { Альберт Р. Мак- } \\
\text { мін }\end{array}$} & $\begin{array}{l}\text { Коефіцієнт середньої обо- } \\
\text { ротності кредиторської } \\
\text { заборгованості }\end{array}$ & $\begin{array}{l}\text { Собівартість проданих това- } \\
\text { рів / Середня заборгованість }\end{array}$ & $\begin{array}{l}\text { показує скільки потрібно оборо- } \\
\text { тів для оплати виставлених ра- } \\
\text { хунків. }\end{array}$ \\
\hline & $\begin{array}{l}\text { Середня кількість днів } \\
\text { заборгованості }\end{array}$ & $\begin{array}{l}365 \text { / Коефіцієнт заборгова- } \\
\text { ності }\end{array}$ & $\begin{array}{l}\text { характеризує скільки днів кожна } \\
\text { одиниця заборгованості приймає } \\
\text { участь у виробничому процесі }\end{array}$ \\
\hline & $\begin{array}{l}\text { Коефіцієнт «заборгова- } \\
\text { ність/власний капітал» }\end{array}$ & $\begin{array}{l}\text { Сукупні зобов’ язання (без } \\
\text { довгострокової заборгова- } \\
\text { ності) / Власний капітал }\end{array}$ & $\begin{array}{l}\text { характеризує співвідношення } \\
\text { залученого і власного капіталу у } \\
\text { структурі капіталу підприємства }\end{array}$ \\
\hline
\end{tabular}

* Складено авторами з використання джерел [25-30]

В економічній літературі з сучасних підходів до аналізу кредиторської заборгованості виділені найбільш розповсюджені питання [11]:
- величини, динаміки, складу і структури його заборгованості;

- якості заборгованості; 
- причин, які зумовили виникнення та існування (непогашення) заборгованості;

- частоти виникнення та погашення заборгованості;

- впливу заборгованості на фінансовий стан підприємства;

- доцільності вкладання коштів у заборгованість підприємства тощо.

Ми розділяємо думку Тютюнник Ю.М., що аналіз кредиторської заборгованості необхідно проводити за наступною послідовністю етапів [31]:

- оцінювання величини, структури та динаміки кредиторської заборгованості за видами 3 використанням прийомів горизонтального і вертикального аналізу;
- дослідження структури кредиторської заборгованості за строками утворення 3 метою з'ясування стану платіжної дисципліни;

- комплексне оцінювання кредиторської заборгованості за системою відносних показників;

- порівняльний аналіз дебіторської та кредиторської заборгованості.

За результатами дослідження підходів до аналізу кредиторської заборгованості, зокрема, на базі формі №1 «Баланс (Звіт про фінансовий стан)», проведемо аналіз кредиторської заборгованості за наведеними етапами на прикладі підприємства харчової промисловості з виробництва какао, шоколаду та цукрових кондитерських виробів. По-перше, розглянемо аналіз складу, структури та динаміки кредиторської заборгованості [32] (табл. 3).

Таблиця 3

Аналіз складу, структури та динаміки кредиторської заборгованості підприємства харчової промисловості*

\begin{tabular}{|c|c|c|c|c|c|c|c|c|}
\hline \multirow[b]{2}{*}{ Показники } & \multicolumn{2}{|c|}{$\begin{array}{c}\text { Абсолютна } \\
\text { величина }\end{array}$} & \multicolumn{2}{|c|}{$\begin{array}{l}\text { Питома } \\
\text { вага, \% }\end{array}$} & \multicolumn{4}{|c|}{ Відхилення } \\
\hline & 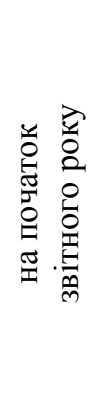 & 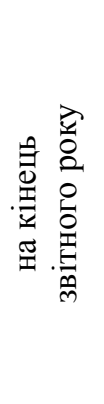 & 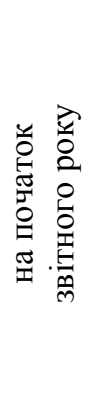 & 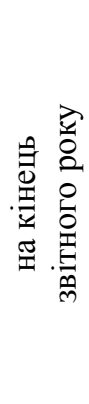 & 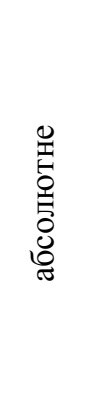 & 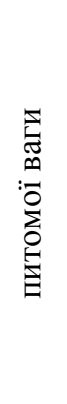 & 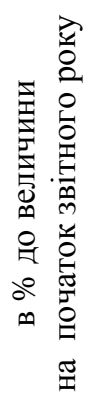 & 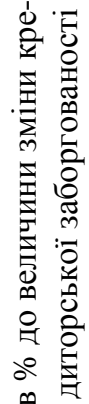 \\
\hline \multirow{2}{*}{$\begin{array}{l}\text { Кредиторська заборгованість всього, } \\
\text { в тому числі: } \\
\text { 1.1. Кредиторська заборгованість за } \\
\text { товари, роботи, послуги }\end{array}$} & 23682 & 19545 & 100 & 100 & -4137 & $\mathrm{x}$ & $-17,5$ & 100 \\
\hline & 19248 & 15645 & 81,3 & 80,0 & -3603 & $-1,2$ & $-18,7$ & 87,1 \\
\hline $\begin{array}{l}\text { 1.2. Кредиторська заборгованість за } \\
\text { розрахунками: }\end{array}$ & 3978 & 3817 & 16,8 & 19,5 & -161 & 2,7 & $-4,0$ & 3,9 \\
\hline \multirow{9}{*}{$\begin{array}{l}\text { - за довгостроковими зобов'язаннями } \\
-3 \text { бюджетом, } \\
\text { у т.ч. } 3 \text { податку на прибуток } \\
\text { - зі страхування } \\
\text { - з оплати праці } \\
\text { - за одержаними авансами } \\
\text { - за розрахунками з учасниками } \\
\text { - із внутрішніх розрахунків } \\
\text { 1.3. Інші поточні зобов'язання }\end{array}$} & - & - & - & - & - & - & - & - \\
\hline & 1932 & 641 & 8,2 & 3,3 & -1291 & $-4,9$ & $-66,8$ & 31,2 \\
\hline & - & - & - & - & - & - & - & - \\
\hline & 697 & 547 & 2,9 & 0,0 & -150 & $-2,9$ & $-21,5$ & 3,6 \\
\hline & 1239 & 2357 & 5,2 & 12,1 & 1118 & 6,8 & 90,2 & $-27,0$ \\
\hline & 110 & 272 & 0,5 & 1,4 & 162 & 0,9 & 147,3 & $-3,9$ \\
\hline & - & - & - & - & - & - & - & - \\
\hline & - & - & - & - & - & - & - & - \\
\hline & 456 & 83 & 1,9 & 0,4 & -373 & $-1,5$ & $\begin{array}{l}-81,8 \\
\end{array}$ & 9,0 \\
\hline
\end{tabular}

*Розраховано авторами за даними фінансової звітності підприємства

3 табл. 3 видно, що кредиторська заборгованість на кінець звітного періоду порівняно з початком зменшилась на 4137 тис. грн., або на 17,5\%. Це відбулось за рахунок зменшення кредиторської заборгованості за товари, роботи, послуги на 3603 тис. грн., або в $18,7 \%$, інших поточних зобов'язань на 373 тис. грн., або на $81,8 \%$ та кредиторської заборгованості за розрахунками на 161 тис. грн., або на 4,0\%. В структурі кредиторської заборгованості на початок звітного року найбільшу питому вагу займала заборгова- ність за товари, роботи, послуги - 81,3\%, питома вага кредиторської заборгованості за розрахунками $16,8 \%$, інші поточні зобов'язання - 1,9\%. На кінець звітного року відбулись наступні зміни в структурі кредиторської заборгованості: зменшилась питома вага кредиторської заборгованості за товари, роботи, послуги на $1,2 \%$ пункти та питома вага інших поточних зобов'язань на 1,5\% пункти. Питома вага кредиторської заборгованості за розрахунками збільшилась на 2,7\% пункти. 
Слід відмітити, що початковою інформацією для складання кредиторської заборгованості є дані бухгалтерського обліку з грошової позики конкретних контрагентів, а також і про терміни її виникнення.

На думку Томчука О.Ф. найважливішим з погляду управління $є$ розподіл заборгованості підприємства за термінами погашення. Поділ заборгованості на довготермінову та поточну необхідний для оцінювання ліквідності та платоспроможності підприємства. Крім того, групують поточну заборгованість за термінами іiі виникнення, найчастіше виділяючи такі «вікові групи»: до 30 днів, від 31 до 90 днів, від 91 до 180 днів і більше півроку. Таке групування необхідне як для фінансового планування, так і для контролю, зокрема для своєчасного виявлення простроченої, сумнівної та безнадійної заборгованості [11].
На наступному етапі проводиться дослідження кредиторської заборгованості за умовами та строками утворення 3 метою з'ясування стану платіжної дисципліни.

В процесі аналізу кредиторської заборгованості необхідно дати оцінку умов заборгованості, строкам заборгованості, обмеженню використання ресурсів, можливості залучення додаткових джерел фінансування. Стан кредиторської заборгованості характеризують показники: коефіцієнт оборотності кредиторської заборгованості, який показує збільшення (зменшення) комерційного кредиту, який надається підприємству та середній строк оборотності кредиторської заборгованості (відображає середній строк повернення боргів підприємства) (табл. 4).

Стан кредиторської заборгованості*

\begin{tabular}{|l|c|c|}
\hline \multicolumn{1}{|c|}{ Показники } & Попередній рік & Звітний рік \\
\hline 1.Собівартість реалізованої продукції, тис. грн. & 88238 & 47355 \\
\hline 2.Середньорічна сума кредиторської заборгованості, тис. грн. & 27648 & 21613,5 \\
\hline 3.Коефіцістт оборотності кредиторської заборгованості & 3,191 & 2,191 \\
\hline 4.Середній строк оборотності кредиторської заборгованості, днів & 112 & 164 \\
\hline
\end{tabular}

*Розраховано авторами за даними фінансової звітності підприємства

Розрахунки табл. 4 свідчить, що середній строк оборотності кредиторської заборгованості досліджуваного підприємства складає 112-164 днів, та, у відповідності до «вікових груп» [11], поточна заборгованість підприємства відноситься до групи з терміном від 91 до 180 днів.
Наступним етапом аналізу кредиторської заборгованості є оцінювання фінансової стійкості та ліквідності підприємства за системою узагальнюючих та відносних показників [32] за допомогою табл. 5-7.

Аналіз фінансової стійкості за узагальнюючими показниками *

\begin{tabular}{|l|c|c|}
\hline \multicolumn{1}{|c|}{ Показники } & \multicolumn{2}{c|}{ Сума, тис. грн. } \\
\cline { 2 - 3 } & $\begin{array}{c}\text { на початок } \\
\text { звітного року }\end{array}$ & $\begin{array}{c}\text { на кінець } \\
\text { звітного року }\end{array}$ \\
\hline 1. Власний капітал & 24865 & 8563 \\
\hline 2. Необоротні активи & 10102 & 1488 \\
\hline 3. Наявність власних оборотних коштів & 14763 & 1488 \\
\hline 4. Короткострокові кредити банків & - & 14188 \\
\hline 5. Загальна величина джерел формування запасів & 14763 & -12700 \\
\hline 6. Запаси & 18678 & -12700 \\
\hline 7. Надлишок (+) або нестача (-) власних оборотних коштів & -3915 & 15645 \\
\hline $\begin{array}{l}\text { 8. Надлишок (+) або нестача (-) загальної величини джерел } \\
\text { формування запасів }\end{array}$ & -3915 & нестійка \\
\hline 9. Джерела, що послаблюють фінансову напругу & 19248 & нестійка \\
\hline 10. Тип фінансової ситуації на підприємстві &
\end{tabular}

*Розраховано авторами за даними фінансової звітності підприємства

Аналіз фінансової стійкості підприємств за узагальнюючими показниками свідчить про нестійкий стан підприємства (табл. 5), оскільки підприємству не вистачає власних оборотних коштів на покриття запасів і воно вимушено використовувати джерела, що послаблюють фінансову напругу.

Як видно з табл. 6, значення показників підприємства фінансової стійкості підприємства має тен- денцію до їх зменшення, що свідчить про поступову втрату його незалежності. Таким чином, аналіз показників фінансової стійкості досліджуваного підприємства дозволяє зробити висновок про неефективне вкладення грошових коштів в їх діяльність та фінансову нестабільність функціонування підприємств на ринку. 
Таблиця 6

Аналіз фінансової стійкості підприсмства за частковими показниками*

\begin{tabular}{|c|c|c|c|}
\hline Показники & $\begin{array}{c}\text { на початок } \\
\text { звітного оку }\end{array}$ & $\begin{array}{c}\text { на кінець } \\
\text { звітного року }\end{array}$ & $\begin{array}{c}\text { Нормативне } \\
\text { значення }\end{array}$ \\
\hline 1. Коефіцієнт автономії & 0,49 & \begin{tabular}{l|l}
0,26 \\
\end{tabular} & більше 0,5 \\
\hline 2. Коефіцієнт співвідношення залучених та власних коштів & 1,02 & 2,84 & менше 1,0 \\
\hline 3.Наявність власних оборотних коштів & 14763 & 1488 & збільшення \\
\hline 4.Коефіцієнт маневреності власного капіталу & 0,59 & 0,16 & $0,4 \ldots 0,6$ \\
\hline $\begin{array}{l}\text { 5.Коефіцієнт забезпеченості оборотних коштів власними оборот- } \\
\text { ними коштами }\end{array}$ & 0,37 & 0,05 & 0,1 \\
\hline
\end{tabular}

*Розраховано авторами за даними фінансової звітності підприємства

Такі важливі фінансові показники як платоспроможність та ліквідність обчислюються, виходячи з облікових даних про заборгованість за розрахунками та характеризують фінансовий стан кожного окремого підприємства і держави взагалі, впливають на рівень їхньої інвестиційної привабливості, кредитоспроможності, загальної рентабельності діяльності. Аналіз ліквідності підприємства за відносними показниками звітного року наведений в табл. 7.

Таблиця 7

Аналіз ліквідності підприємства за відносними показниками*

\begin{tabular}{|c|c|c|c|}
\hline \multirow[b]{2}{*}{ Коефіцієнти ліквідності підприємства } & \multirow[b]{2}{*}{ Норма } & \multicolumn{2}{|c|}{ Розрахункові значення } \\
\hline & & $\begin{array}{c}\text { на початок } \\
\text { звітного року }\end{array}$ & $\begin{array}{c}\text { на кінець } \\
\text { звітного року }\end{array}$ \\
\hline 1. Коефіцієнт поточної ліквідності (покриття) & $=2,0$ & 1,582 & 1,055 \\
\hline 2.Коефіцієнт швидкої (критичної) ліквідності & 1,0 & 0,846 & 0,533 \\
\hline 3. Коефіцієнт абсолютної ліквідності & $\begin{array}{c}>0,2 \\
{[0,25 \ldots 0,35]}\end{array}$ & 0,004 & 0,007 \\
\hline
\end{tabular}

*Розраховано авторами за даними фінансової звітності підприємства

3 табл. 7 видно, що коефіцієнти швидкої, поточної ліквідності досліджуваного підприємства знаходяться в межах норми, що позитивно характеризує його діяльність та свідчить про його змогу покрити свої термінові зобов'язання, але негативним є невідповідність коефіцієнту абсолютної ліквідності норма- тивному значенню, що свідчить про неможливість погашення підприємством його термінових зобов’ язань абсолютно ліквідними активами.

Завершуючим етапом оцінки кредиторської заборгованості є порівняльний аналіз дебіторської та кредиторської заборгованості (рис. 1).

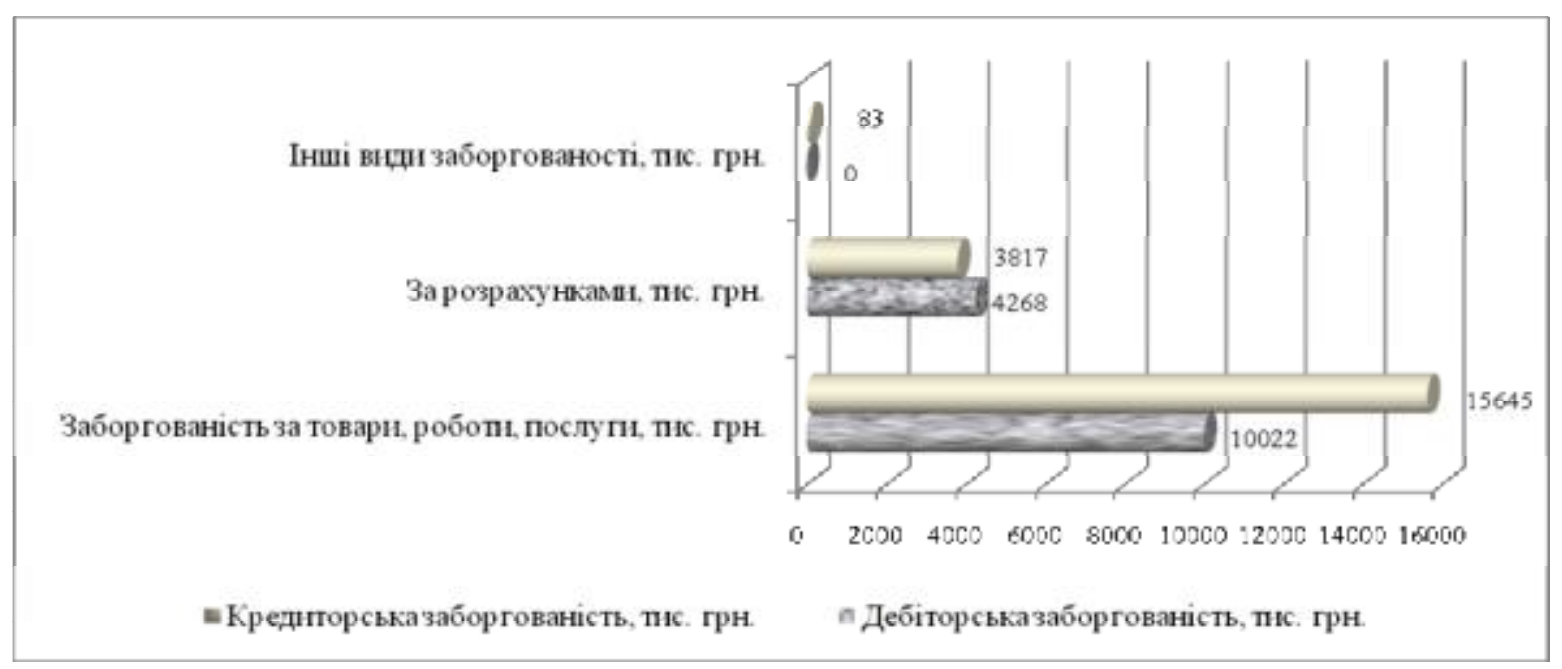

\section{Рис. 1. Порівняльний аналіз дебіторської та кредиторської заборгованості підприсмства* \\ *складено авторами за даними фінансової звітності підприємства}

Результатом порівняльного аналізу $\epsilon$ 3'ясування зменшення чи збільшення дебіторської заборгованості; зменшення чи збільшення кредиторської заборгованості. Зменшення дебіторської забор- гованості проти кредиторської може бути через погіршення стосунків 3 клієнтами, а саме - через зменшення кількості покупців продукції. Збільшення дебіторської заборгованості проти кредиторської може 
може бути наслідком неплатоспроможності покупців. У процесі господарської діяльності частіше кредиторська заборгованість перевищує дебіторську [33]. Отже, аналізуючи стан дебіторської та кредиторської заборгованості, необхідно вивчити причини виникнення кожного виду заборгованості, враховуючи особливості діяльності підприємства та різні ситуації на підприємстві [8].

3 рис. 1 видно, що на кінець звітного року сталося перевищення кредиторської заборгованості над дебіторською в загальній сумі на 5255 тис. грн., або на 36,77\%, а саме: за рахунок кредиторської заборгованості за товари, роботи, послуги на 5623 тис. грн., або на 56,11\%, а також з'явилася заборгованість за іншими видами у розмірі 83 тис. грн. Аналітична оцінка, також свідчить про незначне перевищення дебіторської над кредиторської заборгованості у розмірі 451 тис. грн., або майже $12 \%$ по статті «за розрахунками».

Таким чином, аналіз кредиторської заборгованості, проведений на прикладі підприємства харчової промисловості з виробництва какао, шоколаду та цукрових кондитерських виробів за визначеними етапами показав велику частку кредиторської заборгованості в структурі поточних зобов'язань, нестійкий фінансовий стан, неліквідність балансу, повільний оборот кредиторської заборгованості (112-164 днів), що свідчить про необхідність прийняття управлінських рішень щодо вирішення такої ситуації.

Оцінивши кредиторську заборгованість в контексті фінансової стійкості суб'єкта господарювання, можна визначити причини ії виникнення та оптимальний механізм іï ефективного управління.
Серед основних причин $\epsilon$ [11]:

- кредиторська заборгованість оцінюється за повною ринковою ціною, тоді як дебіторська - за витратами;

- до суми кредиторської заборгованості включено заборгованість перед бюджетом, державними цільовими фондами та 3 виплати заробітної плати.

На думку Томчука О.Ф., основні завдання управління кредиторською заборгованістю полягають в прискоренні платежів зі сторони клієнтів підприємства, зниженні «поганих» боргів (тобто таких боргів, виплати по яким сумнівні або вже точно не поступлять), в проведенні ефективної політики продаж, недопущенні необгрунтованого росту кредиторської заборгованості, особливо невиплаченої в строк, оскільки це приводить до обкладання штрафами, пені, розірвання договірних відносин, загрози забезпечення безперебійності поставок товарно-матеріальних цінностей і т.д. [11].

Обов'язковою умовою досягнення контрольованості процесу розрахунків 3 постачальниками i підрядниками є автоматизація їх обліку, яка сприяє підвищенню його аналітичності та оперативності через вдосконаленню інформаційного обміну й посилення вірогідності інформації [12].

Таким чином, в результаті дослідження заходів щодо підвищення ефективності управління кредиторської заборгованості, запропоновано механізм дієвої системи ефективного управління кредиторської заборгованості (рис. 2).

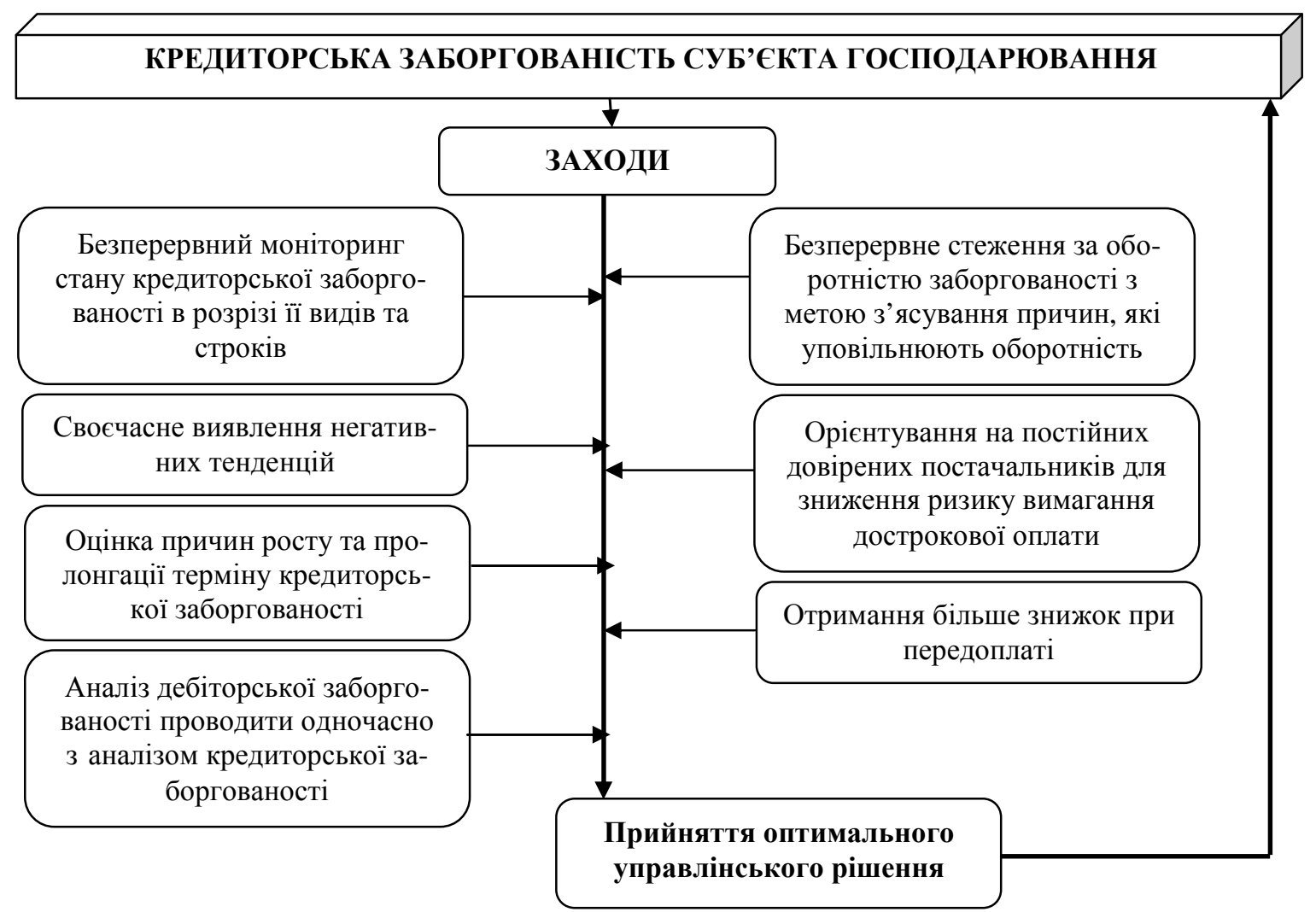

Рис. 2. Механізм дієвої системи ефективного управління кредиторської заборгованості* *розроблено авторами на підставі аналізу джерел [10] 
Висновки та перспективи подальших досліджень. Проведені дослідження підтверджують важливість такої ділянки господарського обліку як кредиторська заборгованість. Поточні зобов'язання тісно пов'язані та впливають на фінансову стійкість, конкурентоспроможність, автономність суб'єктів господарювання. Проведене дослідження категорії «кредиторська заборгованість» в економічній літературі за нормативними актами, дозволило визначити, що це фінансова угода між двома суб'єктами господарювання, в якій одна сторона тимчасово позичає комерційні кошти для грошового обігу, а інша - зобов'язується повернути борг у вказаний термін. Проведений аналіз сучасних підходів до аналізу кредиторської заборгованості дозволив визначити послідовність етапів іiі проведення: оцінювання величини, структури та динаміки кредиторської заборгованості за видами 3 використанням прийомів горизонтального і вертикального аналізу; дослідження структури кредиторської заборгованості за строками утворення з метою з'ясування стану платіжної дисципліни; комплексне оцінювання кредиторської заборгованості за системою відносних показників; порівняльний аналіз дебіторської та кредиторської заборгованості. За даними етапами було проведено аналіз кредиторської заборгованості на прикладі підприємства харчової промисловості, який показав нестійкий фінансовий стан, неліквідність балансу, велику частку кредиторської заборгованості в структурі поточних зобов'язань, про повільний оборот кредиторської заборгованості (112-164 днів) досліджуваного підприємства, що свідчить про необхідність прийняття управлінських рішень щодо вирішення такої ситуації. За результатами дослідження авторами запропоновано механізм заходів, що сприятимуть створенню дієвої системи ефективного управління кредиторською заборгованістю підприємств.

\section{Література}

1. Державна служба статистики України. Оборотні активи підприємств за видами економічної діяльності станом на 31 грудня 2017 року: [Веб-сайт]. Київ, 2017. http://ukrstat.gov.ua/operativ/operativ2013/fin/oaktuvu/oa_ed/oa_ed_u/oa_ed_3_17_u.htm (дата звернення: 27.10.2018).

2. Державна служба статистики України. Поточні зобов'язання і забезпечення підприємств за видами економічної діяльності станом на 31 грудня 2017 року: [Веб-сайт]. Київ, 2017. URL: http://ukrstat.gov.ua/operativ/operativ2013/fin/pz/pz ed/pz_ed_u/pz ed 3 17 u.htm (дата звернення: 27.10.2018).

3. Плаксієнко В.Я., Куклішина О.С. Особливості облікового відображення розрахунків $з$ постачальниками на підприємстві URL: http://www.rusnauka.com/11_NPE_2014/Economics/7 166187.doc.htm (дата звернення: 15.10 .2018$)$.

4. Кодекс Цивільного захисту України за станом на 02.10.2018 р / Верховна Рада України. Київ. URL: http://zakon.rada.gov.ua/laws/main/435-15 (дата звернення: 27.10.2018).

5. Про бухгалтерський облік і фінансову звітність в Україні: Закон України від 16.07.99 р. № 996-XIV за станом на 18.09.2018 р. / Верховна Рада України. Київ. URL: http://zakon.rada.gov.ua/laws/show/996-14 (дата звернення: 05.10.2018).

6. Забезпечення, умовні зобов'язання та умовні активи: Міжнародний стандарт бухгалтерського обліку №37. URL: file:///C:/Users/User/Downloads/MСБО\%2037.pdf (дата звернення: 27.10.2018).

7. Зобов'язання: Положення (стандарт) бухгалтерського обліку 11: затв. наказом Мінфіну від 31.01.2000 р. № 20 за станом на 08.02.2014 p. URL: https://zakon.help/law/20/ (дата звернення: 27.10.2018).

8. Матюха В.І., Мисака Г.В. Актуальні проблеми обліку розрахунків підприємства з постачальниками та підрядниками // Молодий вчений. 2018. №1(2). С. 930-932.

9. Новицька Н.В. Теоретичні аспекти понять «дебіторська заборгованість» і «кредиторська заборгованість» // Актуальні проблеми економіки. 2012. № 2. С. 286-290.

10. Мягких I.M. Методичний підхід до аналізу та оцінки дебіторської та кредиторської заборгованості як складових управління фінансової стійкості авіакомпаній України // Міжнародний науково-виробничий журнал: Сталий розвиток економіки. 2013. № 4 (21). С. 255-262.

11. Томчук О.Ф. Аналітичне забезпечення управління кредиторською заборгованістю підприємства // Науковий вісник ЛНУВМБТ ім. С.3. Гжицького. 2016. Т. 18, вип. 2. С. 160-164.

12. Бутинець Ф.Ф., Горецька Л.Л. Бухгалтерський облік у зарубіжних країнах. Житомир: Рута, 2003. $544 \mathrm{c}$.

13. Лишиленко О.В. Бухгалтерський облік. 3-тє вид., перероб. і доп. К.: Центр учбової літератури, 2009. $670 \mathrm{c}$.

14. Бабаев Ю.А., Комиссарова И.П., Бородин В.А. Бухгалтерский учет / под ред. проф. Ю.А. Бабаева, проф. И.П. Комиссаровой. 2-е изд., перераб. и доп. М.: ЮНИТИ-ДАНА, 2005. 527 с.

15. Финансовый учет / под ред. проф. В.Г. Гетьмана. 3-е изд., перераб. и доп. М.: Финансы и статистика, $2005.816 \mathrm{c}$.

16. Ковальчук І.В. Економіка підприємства. К.: Знання, 2008. 679 с.

17. Іванілов О.С. Економіка підприємства. К.: Центр учбової літератури, 2009. 728 с. 
$288 \mathrm{c}$.

18. Фінанси підприємств (за модульною системою навчання) / В.П. Шило та ін. К: Професіонал, 2006.

19. Учет - 2000: бухгалтерский и налоговый учет.13-е изд., перераб. и доп. Т.1. М.: Статус-Кво 97, 2000.

$552 \mathrm{c}$.

20. Цал-Цалко Ю.С. Фінансовий аналіз. К.: Центр учбової літератури, 2008. 566 с.

$2001.784 \mathrm{c}$

21. Ткаченко Н.М. Бухгалтерський фінансовий облік на підприємствах України. 6-те вид. К.: А.С.К.,

22. Чебанова Н.В., Василенко Ю.А. Бухгалтерський фінансовий облік. К.: Академія, 2002. 672 с.

23. Гарасим П.М., Лобода Н.О., Гарасим М.П. Структурна динаміка зобов'язань підприємства як класична обліково-аналітична парадигма // Економічні науки. Сер.Облік і фінанси. 2014. Вип.11(2). С. 102-110.

24.Горизонтальний (трендовий) аналіз // Економіка та фінанси підприємства. URL: https://pidruchniki.com/1122121364762/ekonomika/gorizontalniy trendoviy analiz (дата звернення: 16.10.2018)

25. Конон Багрій. Характеристика сучасних методів аналізу поточних зобов’язань суб'єкта господарювання // Економічнй аналіз. 2012. Вип.11, част. 2. URL: file:///C:/Users/Admin/Downloads/ecan_2012_11(2) 6\%20(3).pdf (дата звернення: 16.10.2018)

26. Гнатенко С. П., Волошина В. В. Аналіз співвідношення дебіторської та кредиторської заборгованості підприємства // Науковий вісник МНУ ім. В.О. Сухомлинського. Сер. Економічні науки. Миколаїв, 2015. № 1 (4). C. $38-42$

27. Івахненко В. М. Курс економічного аналізу: навч.-метод. посібник. 4-тє вид. К.: Знання, 2004.190 с.

28. Савицька Г. В. Аналіз господарської діяльності підприємства: навч.посібник. 7-е вид. Мн.: Нове знання. 2003. 688 с.

29. Васіна Н.В. Моделювання фінансового стану сільсько-господарських організацій при оцінці їх кредитоспроможності: монографія. Омськ: Изд-во НОУ ВПО ОмГАУ, 2012. С.49.

30. Словник економіко-фінансових показників, коефіцієнтів, індикаторів [Електроний ресурс]. URL : https://www.finalon.com/slovnik-ekonomichnikh-pokaznikiv

31. Тютюнник Ю. М. Фінансовий аналіз: навч. посіб. 2-ге вид., перероб. і доп. част. І. - Полтава : РВВ ПДАА, 2014. 358 с.

32. Антонюк О.П., Ступницька Т.М., Купріна Н.М. Економічний аналіз: навч. посібник. Львів: Магнолія 2006, 2015. 326 c.

33. Кручак Л.В. Аналіз стану дебіторської та кредиторської заборгованості суб'єкта господарювання // Економічний аналіз: зб. наук. праць Тернопільський національний економічний університет, 2016. С. 93-98.

Стаття надійшла 02.10.2018

Стаття прийнята до друку 16.10.2018 Доступно в мережі Internet 29.12.2018

Ступницкая Т.М.

кандидат экономических наук, доцент кафедра учета и аудита

E-mail: t.stupnitska@gmail.com

Бамбуляк И.М. магистрант кафедра учета и аудита E-mail: b irina mih@ukr.net
Маркова Т.Д.

кандидат экономических наук, доцент кафредра учета и аудита

E-mail: markova.tetiana17@gmail.com

\section{Кулик Н.М.}

магистрант кафедра учета и аудита Одесская национальная академия пищевых технологий ул. Канатная, 112, г. Одесса, Украина, 65039

E-mail: natali.kulik.1996@mail.ru

\section{КРЕДИТОРСКАЯ ЗАДОЛЖЕННОСТЬ ПРЕДПРИЯТИЯ: ОЦЕНКА И МЕХАНИЗМЫ УПРАВЛЕНИЯ}

В статье рассмотрено экономическое содержание и подходы к определению категории «кредиторская задолженность» по нормативно-правовым актам и в экономической литературе. Исследованы теоретические подходы и их практическое применение для проведения анализа кредиторской задолженности в современных условиях, с выделением отдельных его этапов: оценки величины, структуры и динамики кредиторской задолженности по видам с использованием приемов горизонтального и вертикального анализа; определение структуры кредиторской задолженности по срокам возникновения для определения состояния платежной дисциплины; комплексная оценка кредиторской задолженности по системе относительных показателей; сравнительный анализ дебиторской и кредиторской задолженности. Проведена оценка величины, структуры и динамики кредиторской за- 
долженности с учетом сроков ее погашения с использованием приемов горизонтального и вертикального анализа и разных методов на примере данных финансовой отчетности предприятия пищевой промышленности; исследована структура кредиторской задолженности по срокам возникновения для определения состояния платежной дисциплины. Проведено комплексное оценивание по системе относительных показателей для определения типа фринансовой устойчивости и платежеспособности предприятия. Для определения доминирующего вида обязательства проведен сравнительный анализ дебиторской и кредиторской задолженности. По результатам исследования авторами предложен механизм, способствующий созданию действенной системы эффрективного управления кредиторской задолженностью предприятий. Определены механизмы эффективного управления для своевременного регулирования текущей кредиторской задолженности предприятия, правильного отражения ее величины в финансовой отчетности предприятия, бесперебойной работы и надежности на арене бизнеса.

Ключевые слова: кредиторская задолженность, экономическое содержание категории «кредиторская задолженность», этапы анализа кредиторской задолженности, управление кредиторской задолженностью.

Stupnytska T.

Ph.D., Associate Professor

Department of Accounting and Auditing

E-mail: t.stupnitska@gmail.com

Bambuliak I.

Undergraduate

Department of Accounting and Auditing

E-mail: $\underline{b}$ irina mih@ukr.net
Markova T.

Ph. D., Associate Professor

Department of Accounting and Auditing

E-mail: markova.tetiana17@gmail.com

Kulik N.

Undergraduate

Department of Accounting and Auditing

Odessa National Academy of Food Technologies

Kanatna str., 112, Odesa, Ukraine, 65039

E-mail: natali.kulik.1996@mail.ru

\section{CREDIT INDEBTEDNESS OF THE ENTERPRISE: EVALUATION AND MANAGEMENT MECHANISMS}

The article deals with the economic content and approaches to the definition of the category "accounts payable" in the normative legal acts and in the economic literature.

The research of theoretical approaches and their practical use for carrying out the analysis of accounts payable in modern conditions, with the allocation of separate stages of it: estimation of the size, structure and dynamics of payables by types with the use of techniques of horizontal and vertical analysis; studying the structure of payables by terms of creating in order to determine the status of payment discipline; complex estimation of accounts payable under the system of relative indicators; comparative analysis of receivables and payables, have been carried out.

Taking into account the various methods and terms of paying off the payables, its estimation of the size, structure and dynamics with the use of methods of horizontal and vertical analysis on the example of the data of financial reporting of the food industry enterprise has been given. The structure of payables according to the terms of appearance has been investigated in order to find out the state of payment discipline. A complex evaluation has been conducted by the system of relative indicators for determining the state of financial stability and solvency of the enterprise. To determine the dominant type of commitment, a comparative analysis of receivables and payables has been carried out.

According to the results of the study, the authors proposed a mechanism of measures that would facilitate the creation of an effective system of efficient management of accounts payable by enterprises. The mechanisms of efficient management have been defined for timely response of current payables, correct reflection of the enterprise in the financial statements and the continuity of work and reliability in the business arena.

Key words: payables, economic content of the category "accounts payable", stages of analysis of accounts payable, management of accounts payable.

\section{References}

1. Deržavna služba statistiki Ukraïni. Oborotnì aktivi pìdpriêmstv za vidami ekonomičnoï diâl'nostì stanom na 31 grudnâ 2017 roku. (2017). Retrieved October 27, 2018, from http://ukrstat.gov.ua/operativ/operativ2013/fin/oaktuvu/oa_ed/oa_ed_u/oa_ed_3_17_u.htm 
2. Deržavna služba statistiki Ukraïni. Potočnì zobov'âzannâ ì zabezpečennâ pìdpriêmstv za vidami ekonomičnoï diâl'nostì stanom na 31 grudnâ 2017 roku. (2017). Retrieved October 27, 2018, from http://ukrstat.gov.ua/operativ/operativ2013/fin/pz/pz_ed/pz_ed_u/pz_ed_3_17_u.htm

3. Plaksiienko, V. Ya., \& Kuklishyna, O. S. (2014). Osoblivostì oblikkovogo vìdobražennâ rozrahunkìv z postačal'nikami na pìdpriêmstvì. $\quad$ Retrieved $\quad$ October $\quad 15, \quad 2018$, from http://www.rusnauka.com/11_NPE_2014/Economics/7_166187.doc.htm

4. Kodeks Civil'nogo zahistu Ukraïni za stanom na 02.10.2018 r. (2018). Retrieved October 27, 2018, from http://zakon.rada.gov.ua/laws/main/435-15

5. Pro buhgalters'kij oblik ì fìnansovu zvìtnìst' v Ukraïnì: Zakon Ukraïni vìd 16.07.99 r. № 996-XIV za stanom na 18.09.2018 r. (2018). Retrieved October 05, 2018, from http://zakon.rada.gov.ua/laws/show/996-14

6. Zabezpečennâ, umovnì zobov’âzannâ ta umovnì aktivi: Mižnarodnij standart buhgalters'kogo oblìku №37. Retrieved October 27, 2018, from file:///C:/Users/User/Downloads/MSBO 37.pdf

7. Zobov'âzannâ: Položennâ (standart) buhgalters'kogo oblìku 11: Zatv. nakazom Mìnfìnu vìd 31.01.2000 r. № 20 za stanom na 08.02.2014 r. (2014). Retrieved October 27, 2018, from https://zakon.help/law/20/

8. Matiukha, V. I., \& Mysaka, H. V. (2018). Aktual'nì problemi oblìku rozrahunkìv pìdpriêmstva z postačal'nikami ta pìdrâdnikami. Molodij Včenij, (1 (2)), 930-932.

9. Novytska, N. V. (2012). Teoretičnì aspekti ponât' «debìtors'ka zaborgovanìst'» ì «kreditors'ka zaborgovanìst'». Aktual'ni Problemi Ekonomiki, (2), 286-290.

10. Miahkykh, I. M. (2013). Metodičnij pìdhìd do analìzu ta ocìnki debìtors'koï ta kreditors'koï zaborgovanostì âk skladovih upravlìnnâ fìnansovoï stìjkostì avìakompanìj Ukraïni. Mižnarodnij Naukovo-virobničij žurnal: Stalij Rozvitok Ekonomiki, (4 (21)), 255-262.

11. Tomchuk, O. F. (2016). Analitične zabezpečennâ upravlìnnâ kreditors'koû zaborgovanìstû pìdpriêmstva. Naukovij Visnik LNUVMBT im. S.Z. Gzhytskoho, 18(2), 160-164.

12. Butynets, F. F., \& Horetska, L. L. (2003). Buhgalters'kij oblik u zarubižnih kraïnah. Zhytomyr: Ruta.

13. Lyshylenko, O. V. (2009). Buhgalters'kij oblik (3rd ed.). Kyiv: Centr učbovoï lìteraturi.

14. Babaev, Yu. A., Komissarova, I. P., \& Borodin, V. A. (2005). Buhgalterskij učet (2nd ed.) (Yu. A. Babaev \& I. P. Komissarova, Eds.). Moskva: ÛNITI-DANA.

15. Getman, V. G. (Ed.). (2005). Finansovyj učet (3rd ed.). Moskva: Finansy i statistika.

16. Kovalchuk, I. V. (2008). Ekonomika pidpriêmstva. Kyiv: Znannâ.

17. Ivanilov, O. S. (2009). Ekonomika pidpriêmstva. Kyiv: Centr učbovoï lìteraturi.

18. Shylo, V. P. (2006). Fìnansi pidpriêmstv (za modul'nô̂ sistemô̂ navčannâ). Kyiv: Profesìonal.

19. Učet - 2000: Buhgalterskij i nalogovyj učet (13th ed., Vol. 1). (2000). Moskva: Status-Kvo 97.

20. Tsal-Tsalko, Yu. S. (2008). Finansovij analiz. Kyiv: Centr učbovoï literaturi.

21. Tkachenko, N. M. (2001). Buhgalters'kij finansovij oblik na pidpriêmstvah Ukraïni (6th ed.). Kyiv: A.S.K.

22. Chebanova, N. V., \& Vasylenko, Yu. A. (2002). Buhgalters'kij finansovij oblik. Kyiv: Akademiâ.

23. Harasym, P. M., Loboda, N. O., \& Harasym, M. P. (2014). Strukturna dinamika zobov'âzan' pì̀dpriêmstva âk klasična oblìkovo-analìtična paradigma. Ekonomičnì Nauki. Cer.Oblik i Fìnansi, (11 (2)), 102-110.

24. Gorizontal'nij (trendovij) analìz. (n.d.). Retrieved October 16, 2018, from https://pidruchniki.com/1122121364762/ekonomika/gorizontalniy trendoviy analiz

25. Konon, B. (2012). Harakteristika sučasnih metodìv analìzu potočnih zobov'âzan' sub'êkta gospodarûvannâ. Ekonomičnij Analiz, (11), 2nd ser. Retrieved $\quad$ October $16, \quad 2018$, from file:///C:/Users/Admin/Downloads/ecan_2012_11(2)_6 (3).pdf.

26. Hnatenko, Ye. P., \& Voloshyna, V. V. (2015). Analìz spìvvìdnošennâ debìtors'koï ta kreditors'koï zaborgovanostì pìdpriêmstva. Naukovij Visnik MNU im. V.O. Sukhomlynskoho, (1 (4)), ekonomicnì nauki, 38-42.

27. Ivakhnenko, V. M. (2004). Kurs ekonomičnogo analizu (4th ed.). Kyiv: Znannâ.

28. Savytska, H. V. (2003). Analiz gospodars'koï diâl'nostì pidpriêmstva (7th ed.). Mn.: Nove znannâ.

29. Vasina, N. V. (2012). Modelûvannâ finansovogo stanu sil's'ko-gospodars'kih organizacìj pri ocincì ïh kreditospromožnostì. Omsk: Izd-vo NOU VPO OmGAU.

30. Slovnik ekonomìko-fìnansovih pokaznikìv, koefìciêntìv, ìndikatorìv. Retrieved from https://www.finalon.com/slovnik-ekonomichnikh-pokaznikiv

31. Tiutiunnyk, Yu. M. (2014). Finansovij analiz (2nd ed., Ser. 1). Poltava: RVV PDAA.

32. Antoniuk, O. P., Stupnytska, T. M., \& Kuprina, N. M. (2015). Ekonomičnij analiz. Lviv: Magnoliâ 2006.

33. Kruchak, L. V. (2016). Analìz stanu debìtors'koï ta kreditors'koï zaborgovanostì sub'êkta gospodarûvannâ. Ekonomičnij analiz: Zb. nauk. prac' Ternopil's'kij nacional'nij ekonomičnij universitet (pp. 93-98).

Received 2 October 2018

Approved 16 October 2018

Цитування згідно ДСТУ 8302:2015

Available in Internet 29.12.2018

Ступницька Т.М., Маркова Т.Д., Бамбуляк І.М., Кулік Н.М. Кредиторська заборгованість підприємства: оцінка та механізми управління // Економіка харчової промисловості. 2018. Т. 10, Вип. 4. С. 66-78.

doi: 10.15673/fie.v10i4.1134

Cite as APA style citation

Stupnytska T., Markova T., Bambuliak I., \& Kulik N. (2018). Credit indebtedness of the enterprise: evaluation and management mechanisms. Food Industry Economics, 10(4), 66-78; doi: 10.15673/fie.v10i4.1134 